\title{
Microbial Activity of a Clay Soil Amended with Glucose and Starch Under Live Oaks
}

\author{
Tomás Martínez-Trinidad, W. Todd Watson, Michael A. Arnold, and Leonardo Lombardini
}

\begin{abstract}
Research was conducted to investigate the effect of glucose and starch on soil respiration under live oaks. Soil from a field-grown tree nursery was amended with glucose $\left(\mathrm{C}_{6} \mathrm{H}_{12} \mathrm{O}_{6}\right)$, starch $\left(\mathrm{C}_{6} \mathrm{H}_{12} \mathrm{O}_{6}\right)_{n}$, or a 50:50 mixture of both carbohydrates at increasing concentrations $(0,40,80$ and $120 \mathrm{~g} / \mathrm{L}$ ). Solutions were applied once as $10-\mathrm{L}$ drenches within $0.5 \mathrm{~m}$ from the trunks of live oaks (Quercus virginiana P. Miller). In a companion study, soil samples treated with the same carbohydrates and concentrations were studied under laboratory conditions. Carbon dioxide evolution was significantly impacted by glucose and starch applications. Glucose applications caused a significant increase in soil respiration compared with the control within a week after application, and it lasted two to three weeks. Elevated soil respiration was most noticeable in the field experiment for starch treatments; however, the increase in soil respiration for higher concentrations $(120 \mathrm{~g} / \mathrm{L})$ did not become apparent until the fourth week after application and lasted eight to nine weeks. This knowledge about the differing durations and magnitude of glucose and starch on soil respiration may be useful for developing carbohydrate application regimes for soils where increase respiration is desirable for managing urban trees.

Key Words: Carbohydrate Amendments; Soil Respiration; Sugars.
\end{abstract}

Microbial activity can be used as an indicator of soil quality and to assess effectiveness of soil treatments or cultural practices (Chidthaisong and Conrad 2000; Ilstedt et al. 2000). Microorganism density affects the rate of organic compound transformation in soils. Microorganism populations play an important role in mineralization, nutrient mobilization, and as a temporal sink for nutrients (Schmidt et al. 1997a; Schmidt et al. 2000). Other benefits of microbial activity are enhancement of soil structure and increases in organic matter and symbiotic relationships, such as those established between plants and mycorrhizae (Wagner and Wolf 2005). These beneficial effects of microorganisms have a positive impact on the growth and vitality of trees and other plants (Harmer and Alexander 1986; Sanginga et al. 1992).

Soil microbial activity is highly influenced by carbon substrates in the soil (Jonasson et al. 1996). Plants supply microorganisms with carbon as an energy source through root exudates and root tissues (Schmidt et al. 1997b; Ros et al. 2003). Microorganisms can also be a substrate for other microbes in soils (Wardle and Parkinson 1990). Soils contain a limited amount of carbon with respect to the requirements by soil microbial populations (Smith and Paul 1990; Michelsen et al. 1999). Therefore, different types of amendments such as municipal waste and sewage, organic matter, or carbohydrates have been recommended to recover or improve soil quality (Pascual et al. 1997; Pascual et al. 1999; Ros et al. 2003). Recently, use of soilapplied carbohydrates has been recommended as a potential arboricultural practice for improving tree growth (Percival et al. 2004; Percival and Fraser 2005; Martínez-Trinidad et al. 2009a).

Soil respiration methods have been used to determine microbial activity (Anderson 1982; Zuberer 1994). Soil respira- tion is considered to be the most nonspecific measurement of microbial activity (Tate 2000), and previous research indicated a relationship between $\mathrm{CO}_{2}$ emitted by soil respiration and microbial activity (Tate 2000; Ros et al. 2003). Although some research has been conducted to evaluate the effects of soil-applied carbohydrates on microbial activity or plant growth (Schmidt et al. 1997a; Schmidt et al. 1997b), most of the experiments were conducted using low sugar concentrations with short-time effects on microbial activity on plants grown under laboratory or greenhouse conditions (Ilstedt et al. 2000; Schmidt et al. 2000). Some research has suggested the use of carbohydrate applications to improve growth of trees for urban environments (Percival et al. 2004; Martínez-Trinidad et al. 2009a), but additional studies on the effect of carbohydrates on soil microorganisms or the differing effects among simple and complex carbohydrates on microbial activity at tree nurseries should be considered.

The objective of this study was to evaluate the effect of soil-applied carbohydrates at varying doses on soil microbial activity in a clay soil under controlled and field conditions.

\section{MATERIAL AND METHODS}

\section{Treatments and Soil Sampling}

The field portion of the study was conducted at a nursery containing seven-year-old live oaks (Quercus virginiana) located in Monaville, Texas, U.S. (2957'1.59'N, 96³'28.73”'W). Live oak is often grown in this area and commonly transplanted into urban environments (Arnold 2008). The soil was a Lake Charles clay type, which is taxonomically described as fine, smectitic, 
hyperthermic Typic Hapluderts, and defined as a deep, moderately well drained, very slowly permeable soil type (Soil Survey Staff 2004). The soil is very dark gray with medium-to-fine granular structure with a clay content about $60 \%$, silt content about $34 \%$, and organic matter of surface horizons from $2.5 \%$ to $4 \%$. The upper soil horizon was acidic (6-6.5), but alkalinity increased uniformly with depth (7.8-8.2 at $1.5 \mathrm{~m}$ ) or more. Treatments were applied at the beginning of the study at concentrations of 40,80 , and $120 \mathrm{~g} / \mathrm{L}$. The ten treatments were glucose $\left(\mathrm{C}_{6} \mathrm{H}_{12} \mathrm{O}_{6}\right)$, starch $\left(\mathrm{C}_{6} \mathrm{H}_{12} \mathrm{O}_{6}\right)$, or a 50:50 glucose:starch mixture $(\mathrm{w} / \mathrm{w})$ derived from corn (Zea mays L.) each at the three concentrations, and a water control. Treatment concentrations were chosen based on previous research using soil carbohydrate applications around trees (Schmidt et al. 2000; Percival et al. 2004; Martínez-Trinidad et al. 2009a). Treatments were randomly distributed among the trees with three replicates per treatment. The solutions were applied as drenches within a $0.5 \mathrm{~m}$ radius around the trunk using $10 \mathrm{~L}$ per tree on June 27,2005 . The volume of solution used was sufficient to saturate at least the top $15 \mathrm{~cm}$ of soil.

Two soil cores ( $25 \mathrm{~mm}$ diameter $\times 150 \mathrm{~mm}$ long) were extracted and combined using a soil probe (AMS Inc., American Falls, ID) on the upper soil within a distance of $0.5 \mathrm{~m}$ from each trunk every week. Coarse and fine roots and macroscopic parts of plants were removed from the soil. Immediately after collection, samples were stored on ice and transported to the laboratory. Once in the laboratory, the samples were stored at $4^{\circ} \mathrm{C}\left(39.2^{\circ} \mathrm{F}\right)$ until processing (less than 24 hours). Soil samples for measuring soil respiration as $\mathrm{CO}_{2}$ evolution were collected from the nursery before treatment applications and then on a weekly basis for a period of six weeks.

\section{Estimate of Field Soil Respiration}

Previous research showed that measurement of $\mathrm{CO}_{2}$ evolution is a generally convenient, rapid, and accurate method for assessment of soil microbial activity (Anderson 1982; Bååth and Arnebrant 1994; Tate 2000). Microbial activity was estimated by measuring soil respiration using the alkali trap method (Anderson 1982). A subsample of $60 \mathrm{~g}$ of soil from each soil sample was placed into a glass jar. A small beaker with $3 \mathrm{~mL}$ of $1.0 \mathrm{~N} \mathrm{NaOH}$ was placed over the soil in the jar. Jar lids were tightened to avoid gas leakage and incubated at $27^{\circ} \mathrm{C}\left(80.6^{\circ} \mathrm{F}\right)$ for 24 hours. After incubation, two drops of phenolphthalein and $1 \mathrm{~mL} \mathrm{BaCl}_{2}(50 \%$ solution) were added to precipitate carbonates. Samples were then titrated with $1.0 \mathrm{~N} \mathrm{M} \mathrm{HCl}$, and $\mathrm{CO}_{2}$ evolution was estimated based on the amount of $\mathrm{HCl}$ required in the titration (titration was obtained once the pink color of the solution disappeared). The amount of $\mathrm{CO}_{2}$ released by blank samples was estimated by repeating the same process in jars without soil. The amount of $\mathrm{CO}_{2}$ evolved from soil was then determined following the calculations described by Anderson (1982). Average air temperature in the field during the study period was $23.3^{\circ} \mathrm{C}\left(73.9^{\circ} \mathrm{F}\right)$ $\left[34.8^{\circ} \mathrm{C}\left(94.5^{\circ} \mathrm{F}\right)\right.$ maximum and $19^{\circ} \mathrm{C}\left(66.2^{\circ} \mathrm{F}\right)$ minimum], while the average soil temperature in the top $15 \mathrm{~cm}$ was $25^{\circ} \mathrm{C}\left(77^{\circ} \mathrm{F}\right)$.

To determine the impact of temperature and season on respiration rates, additional samples were collected at another site within the same nursery with similar soil conditions during the winter of 2006 (treatment application on January 30, 2006) and compared to the results obtained from summer 2005 following the same method previously described. The average winter temperature during the study period was $17.6^{\circ} \mathrm{C}\left(63.6^{\circ} \mathrm{F}\right)\left[23.4^{\circ} \mathrm{C}\right.$ $\left(74.1^{\circ} \mathrm{F}\right)$ maximum and $11.8^{\circ} \mathrm{C}\left(53.2^{\circ} \mathrm{F}\right)$ minimum], and the average soil temperature in the top $15 \mathrm{~cm}$ was $16^{\circ} \mathrm{C}\left(60.8^{\circ} \mathrm{F}\right)$.

\section{Estimate of Laboratory Soil Respiration}

To study soil respiration under controlled temperature conditions, another experiment was performed using 30 soil samples collected from other trees at the nursery and kept separated under laboratory conditions during the summer period. As in the prior two experiments, samples were collected from the top 15 $\mathrm{cm}$ of soil at the nursery and placed in open small plastic containers $18 \mathrm{~cm}$ long $\times 12 \mathrm{~cm}$ wide $\times 7 \mathrm{~cm}$ deep (Rubbermaid ${ }^{\circledR}$; Wooster, $\mathrm{OH})$. The soil samples were transported to the laboratory and kept in an incubator at $27^{\circ} \mathrm{C}\left(80.6^{\circ} \mathrm{F}\right)$ under dark conditions throughout the assay. The same carbohydrate concentrations as those used in the field experiment at proportional solution amounts $(200 \mathrm{~mL})$ were applied at the beginning of the experiment. Soil moisture was kept constant $(25 \%)$ throughout the experiment by weighing the container every 48 hours and adding distilled water as needed. Soil respiration was measured weekly for nine weeks using the methodology previously described.

\section{Data Analysis}

Treatments were applied in a completely randomized design with three replicates and including time in the analysis. The data were analyzed using type III sums of squares in the GLM procedure using SPSS statistical software v. 13 (SPSS Inc., Chicago, IL). When a significant $(P<0.05)$ treatment $\times$ time interaction was detected, the treatment means were compared using Dunnett's one-tailed t-test for differences from the appropriate control over time at significance level of 0.05 . The normality assumptions were met by the data.

\section{RESULTS AND DISCUSSION}

\section{Field Studies of Soil Respiration}

A significant interaction $(P<0.001)$ between treatment and time was found for soil respiration during the summer. Respiration rates significantly $(P<0.05)$ increased one week after application for all glucose concentrations (Figure 1a). Higher rates of respiration recorded soon after glucose applications suggest that the substrate was easily utilized by microbes (Schmidt et al. 1997a). The increase in respiration rates for the $120 \mathrm{~g} / \mathrm{L}$ glucose concentration remained high until the third week after treatments under field conditions, while the effect by the lower glucose concentrations (40 and $80 \mathrm{~g} / \mathrm{L}$ ) lasted only until the second week (Figure 1a). Respiration rates after glucose treatments had similar short-term increases as those reported in previous research using soil amended with glucose (Oades and Wagner 1971; Wu et al. 1993; Jonasson et al. 1996; Illeris and Jonasson 1999).

When starch was applied at 40 and $80 \mathrm{~g} / \mathrm{L}$, there was a significant increase $(P<0.05)$ in respiration during the second week after treatments (Figure 1b). The highest concentration $(120 \mathrm{~g} / \mathrm{L})$ of starch did not significantly increase respiration until the fourth and fifth weeks. These results may have been caused by the high amounts of applied starch, which altered the carbon/nitrogen ratio in the soil, or by a low amount of starchdegrading enzymes present in the soil (Wagner and Wolf 2005). 
Starch applications had a less pronounced effect than glucose during the first few weeks after application, but the effect was more prolonged in the highest concentrations. Previous research found that $10 \%$ to $20 \%$ of the starch was still present in the soil six weeks after application (Papavizas et al. 1968).

Two weeks after application, respiration rates in soil treated with the 50:50 carbohydrate mixture was significantly higher than in the control $(P<0.05)$ for the 80 and $120 \mathrm{~g} / \mathrm{L}$ concentrations (Figure 1c). This effect lasted until the fifth week for the $120 \mathrm{~g} / \mathrm{L}$ carbohydrate mixture. The early increase in respiration rates could have been mainly affected by the glucose portion of these treatments since the rates are between those observed for the glucose and starch treatments. The lowest mixture concentration $(40 \mathrm{~g} / \mathrm{L})$ did not have a significant impact on respiration rate. As mentioned previously, the effect of the glucose amount used in low concentrations disappeared in about a week after the treatment (Cheshire 1979; Dassonville et al. 2004), while the small amount of starch $(20 \mathrm{~g} / \mathrm{L})$ in the mixture with the least concentration did not have a significant effect. Rates comparable to the higher mixture concentration have been reported to have an indirect effect on tree vitality (Martínez-Trinidad et al. 2009a).

Respiration values after glucose and starch amendments during the winter 2006 had a similar effect to summer 2005 results. The highest concentration of glucose $(120 \mathrm{~g} / \mathrm{L})$ increased soil respiration during the first and third week (Figure 2a), while the $120 \mathrm{~g} / \mathrm{L}$ starch concentration had significant differences starting in the fifth week and continuing through the ninth week (Figure $2 b)$. The high variability and decrease in the effect of the starch and glucose on soil respiration could have been affected by the rainfall present during the first few weeks after treatment applications. Rainfall may have caused a loss of glucose by leaching, while starch was less leached since it was still visually detected and high microbial activity values were still evident in the ninth week for the higher concentration. Previous research indicated that microbial activity can be stimulated for several weeks by incorporation of carbon sources (Ros et al. 2003).

In the case of the 50:50 mixtures (glucose:starch), the treatments caused significant differences during the first and third weeks after sugar applications for the $80 \mathrm{~g} / \mathrm{L}$ and $120 \mathrm{~g} / \mathrm{L}$ concentrations (Figure 2c). The lack of effects by the lower concentration $(40 \mathrm{~g} / \mathrm{L})$ may have been a result of the low amount of glucose at a $50 \%$ rate $(20 \mathrm{~g} / \mathrm{L})$ being more easily used by microorganisms or lost due to environmental factors (rainfall) or irrigation (Tate 2000). Starch at 50\% (20 g/L) did not cause any significant effect on soil respiration (Figure 2c).

\section{Laboratory Studies of Soil Respiration}

Respiration values for samples that were maintained under laboratory conditions were also differently affected $(P<0.05)$ by the carbohydrate amendments through time (Figure $3 \mathrm{a}-$ Figure 3c). A week after glucose applications, respiration values were higher than those for the field experiment. Reasons for this early response may be attributed to the time of year that samples were collected from the field. In addition, the plastic containers used in the laboratory experiment might reduce the loss of sugars by leaching as could have happened in the field. For future research, the use of containers without drainage should be avoided in order to produce more realistic field conditions. The higher concentrations induced greater respiration

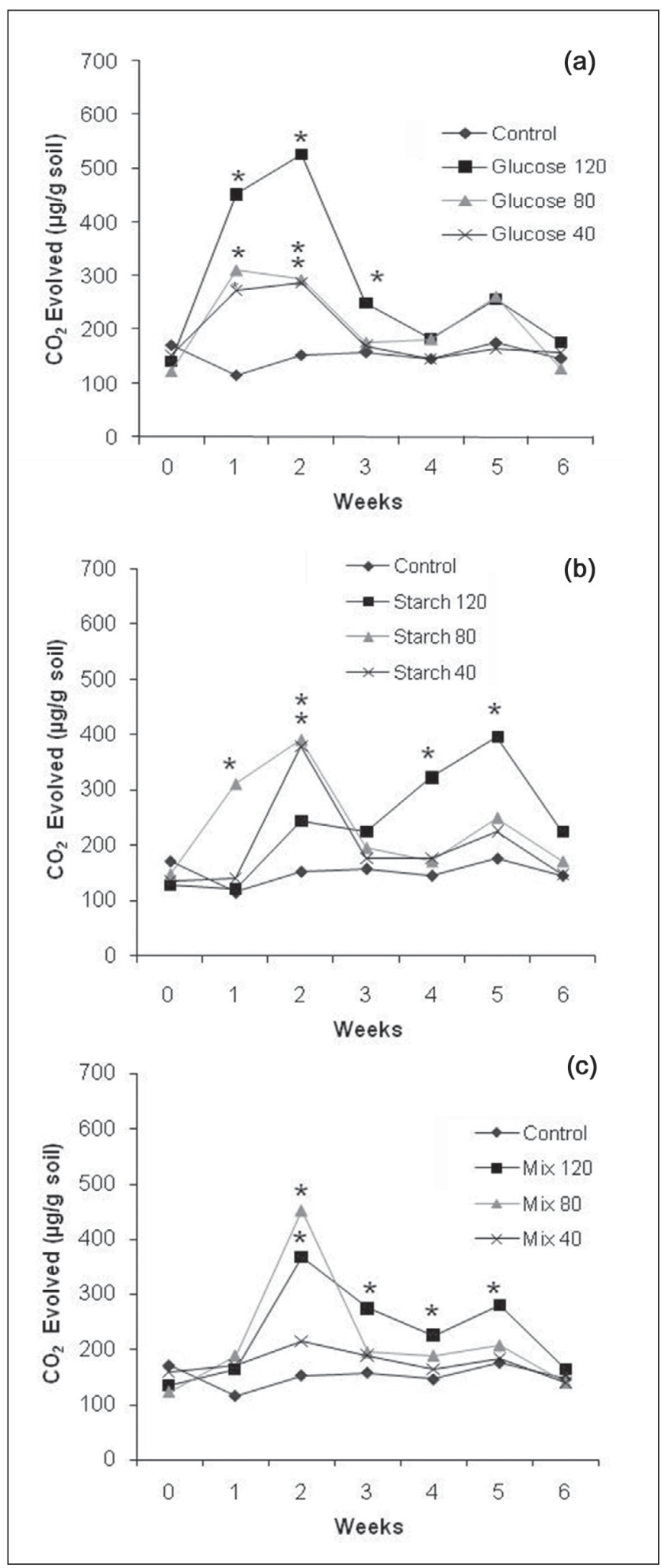

Figure 1. Respiration in soil samples amended with glucose (a), starch (b), and a 50:50 (glucose:starch) mixture (c) at 0, 40, 80, and $120 \mathrm{~g} / \mathrm{L}$ under field conditions (summer 2005). Asterisk (*) indicates significant differences compared to the control on each date using Dunnet's test $(P<0.05)$. 


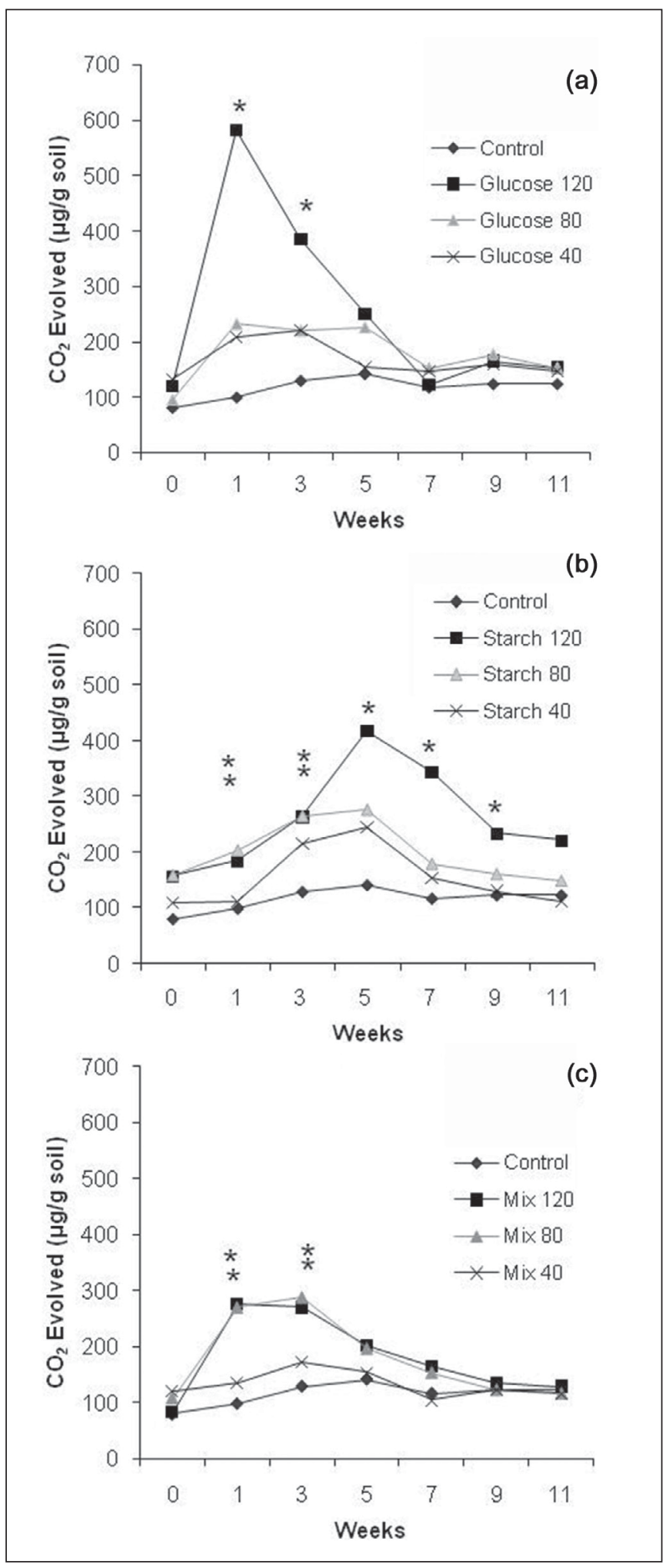

Figure 2. Respiration in soil samples amended with glucose (a), starch (b), and a 50:50 (glucose:starch) mixture (c) at 0, 40, 80, and $120 \mathrm{~g} / \mathrm{L}$ under field conditions during winter 2006. Asterisk ( $\left.{ }^{*}\right)$ indicates significant differences compared to the control using Dunnet's test $(P<0.05)$. rates than the control until the fourth week in the case of glucose at $80 \mathrm{~g} / \mathrm{L}$, and the fifth week for the $120 \mathrm{~g} / \mathrm{L}$ concentration. The fact that the significant effect of sugars was prolonged under laboratory conditions could also be caused by the reduction in microbial colonies as a result of the change in growth conditions as it is reported in other laboratory studies (Zuberer 1994).

Starch treatments did not produce a significant effect on respiration during the first few weeks (Figure 3b); however, starch at $120 \mathrm{~g} \cdot \mathrm{L}^{-1}$ caused a significant increase in respiration values during the sixth week, and the effect lasted until the end of the experiment (ninth week). Previous research revealed a lag phase after the addition of organic polymers due to the synthesis and activity of extracellular enzymes that participated in the degradation of more complex compounds (Ros et al. 2003). Guggenberger et al. (1999) pointed out that the slow decomposition rate of starch was due to the low nutrient availability, mainly nitrogen. The delayed response of soil microbial populations to starch substrates that are not as easily metabolized as glucose may be due to an alteration of the carbon/nitrogen ratio in the soil by the carbon in the starch. Regardless of the type of substrate added, soil respiration usually decreased with time as a consequence of substrate metabolism by microorganisms (Dassonville et al. 2004).

The mixture treatments also increased respiration compared with the control (Figure 3c). The effect lasted until the second week for the $80 \mathrm{~g} / \mathrm{L}$ concentration, and until the fourth week for the $120 \mathrm{~g} / \mathrm{L}$ concentration. Soil treated with mixtures at 120 and $80 \mathrm{~g} / \mathrm{L}$ also exhibited an increase in respiration during the eighth and ninth week. This effect could be due to starch utilization as seen in the starch treatment (Figure 3b). When compared to the field experiment, carbohydrate metabolization may be temperature-dependent with the simpler sugars (glucose) being broken down more quickly and at lower temperatures than the more complex carbohydrates (starch), which likely required higher temperatures, more time, or both (Tate 2000).

\section{CONCLUSIONS}

There is still much that needs to be understood about the potential for using carbohydrates to improve soil conditions and indirectly plant growth or health. Modification of microbial activity through the use of sugar should be done carefully because carbohydrate introduction might negatively impact soils when pathogenic microorganisms are present. The addition of carbohydrates, such as starch used in this study, to the soil has been investigated for combatting Fusarium root rot (Fusarium spp.) which can be another reason for using starch as soil amendment (Tramier and Antonini 1977; Gupta 1986).

The short term increase in soil respiration when applying glucose to the soil, as observed in this study, might explain the null indirect effect found on tree growth in a concurrent study within this tree nursery (Martínez-Trinidad et al 2009a). Indeed, a significant increase in growth was measured on live oaks where sugars were directly injected into the trunks of trees, thereby bypassing the soil (Martínez-Trinidad et al 2009b). However, the use of soil-applied carbohydrates has been recommended as a potential arboricultural practice for improving tree growth and health in urban environments (Percival et al. 2004; Percival and Fraser 2005; Martínez-Trinidad et al. 2009a). 

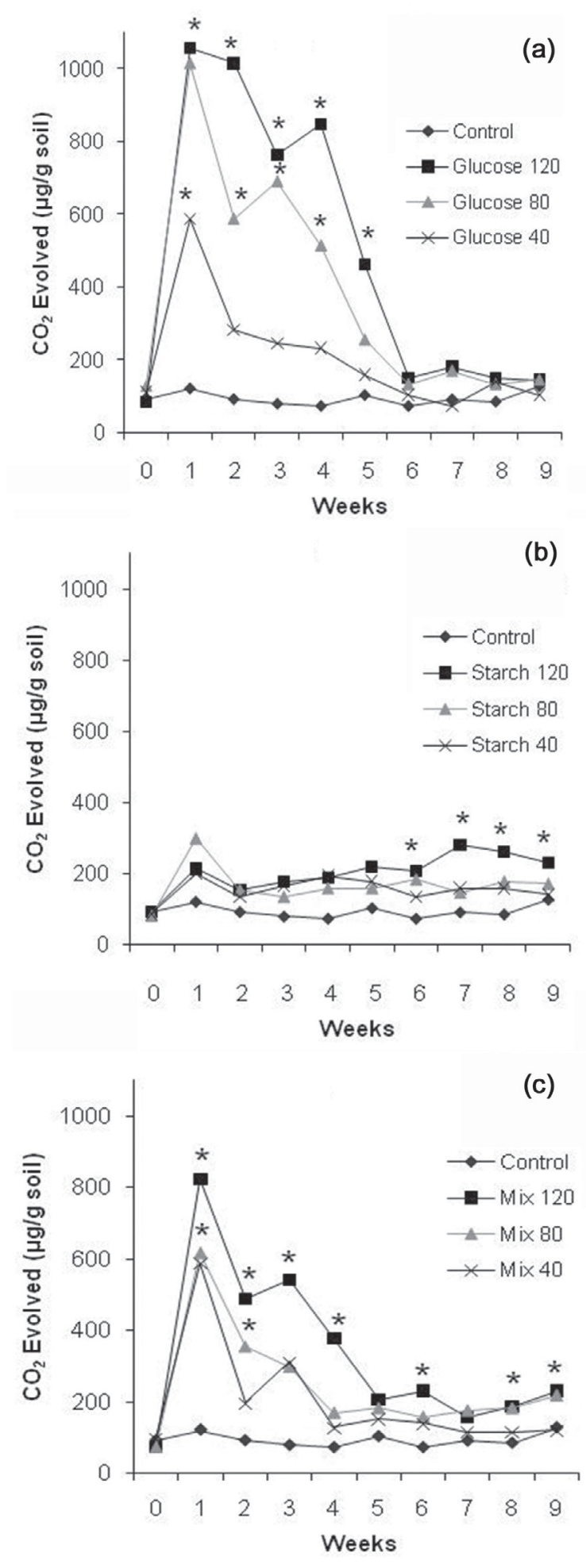

Figure 3. Respiration in soil samples amended with glucose (a), starch (b), and a 50:50 (glucose:starch) mixture (c) at 0, 40, 80, and $120 \mathrm{~g} / \mathrm{L}$ under laboratory conditions (summer 2005). Asterisk ${ }^{*}$ ) indicates significant differences compared to the control using Dunnet's test $(P<0.05)$.
Soil respiration in response to exogenous carbohydrate applications may indicate how carbon sources are a limiting factor for soil microorganisms (Schmidt et al. 2000). In this study, exogenously-applied carbohydrates had differing effects on microbial activity as measured through soil respiration. In general, soil amended with glucose had a rapid and short-lived increase in respiration. The starch effect lasted longer but with a lower effect, and 50:50 mixtures (glucose:starch) tend to have an extended but lower effect caused by the influence of both types of carbohydrates at half rates. The results suggested that glucose and starch as soil amendments can be used as a way to modify short-term microbial activity in soils since the effect of carbohydrates on microbial activity only lasts until carbohydrates are metabolized by soil microorganisms.

Acknowledgments. We thank Environmental Design, Inc., the Texas Forest Service and the USDA Forest Service for supporting this research. We would also like to thank the following people who contributed to this study: Lisbet Islas-Rodriguez, Russell Book, Dudley Bernard, and Alejandro Alarcon.

\section{LITERATURE CITED}

Anderson, J.P.E. 1982. Soil respiration. In: A.L. Page, R.H. Miller, and D.R. Keeney (Eds). Methods of soil analysis, Part 2, Chemical and Microbiological Properties, p. 831-871. ASA and SSSA, Madison, WI.

Arnold, M.A. 2008. Landscape plants for Texas and environs, third edition. Stipes Publishing L.L.C., Champaign, IL.

Bååth, E., and K. Arnebrant. 1994. Growth rate and response of bacterial communities to $\mathrm{pH}$ in limed and ash treated forest soils. Soil Biology \& Biochemistry 26:995-1001.

Cheshire, M.V. 1979. Nature and origin of carbohydrates in soils. Academic Press. NY.

Chidthaisong, A., and R. Conrad. 2000. Turnover of glucose and acetate coupled to reduction of nitrate, ferric iron and sulfate and to methanogenesis in anoxic rice field soil. FEMS Microbiology Ecology 31:73-86.

Dassonville, F., J.J. Godon, P. Renault, A. Richaume, and P. Cambier. 2004. Microbial dynamics in an anaerobic soil slurry amended with glucose and their dependence on geochemical processes. Soil Biology \& Biochemistry 36:1417-1430.

Guggenberger G., E.T. Elliott, S.D. Frey, J. Six, and K. Paustian. 1999. Microbial contributions to the aggregation of a cultivated grassland soil amended with starch. Soil Biology \& Biochemistry 31:407-419.

Gupta, M.C. 1986. Population dynamics of Fusarium species in soil amended with carbonaceous and nitrogenous materials. Indian Phytopatology 39:253-258.

Harmer, R., and I. Alexander. 1986. The effect of starch amendment on nitrogen mineralization from the forest floor beneath a range of conifers. Forestry 59:39-46.

Illeris, L., and S. Jonasson. 1999. Soil and plant $\mathrm{CO}_{2}$ emission in response to variations in soil moisture and temperature and to amendment with nitrogen, phosphorus, and carbon in Northern Scandinavia. Arctic, Antarctic, and Alpine Research 31(3):264-271.

Ilstedt, U., A. Nordgren, and A. Malmer. 2000. Optimum soil water for soil respiration before and after amendment with glucose in humid tropical acrisols and a boreal mor layer. Soil Biology \& Biochemistry 32:1591-1599. 
Jonasson, S., P. Vestergaard, M. Jensen, and A. Michelsen. 1996. Effects of carbohydrate amendments on nutrient partitioning, plant and microbial performance of a grassland-shrub ecosystem. Oikos 75:220-226.

Martínez-Trinidad, T., W.T. Watson, M.A. Arnold, and L. Lombardini. 2009a. Investigations of exogenous applications of carbohydrates on the growth and vitality of live oaks. Urban Forestry \& Urban Greening 8:41-48.

Martínez-Trinidad, T., W.T. Watson, M.A. Arnold, L. Lombardini, and D.N. Appel. 2009b. Carbohydrate injections as a potential option to improve growth and vitality of live oaks. Arboriculture \& Urban Forestry 35:142-147.

Michelsen, A., E. Graglia, I.K. Schmidt, S. Jonasson, D. Sleep, and C. Quarmby. 1999. Differential responses of grass and dwarf shrub to long-term changes in soil microbial $\mathrm{C}, \mathrm{N}$ and $\mathrm{P}$ following factorial addition of NPK fertilizer, fungicide and labile carbon to a heath. New Phytologist 143:523-538.

Oades, J.M., and G.H. Wagner. 1971. Biosynthesis of sugars in soils incubated with ${ }^{14} \mathrm{C}$ glucose and ${ }^{14} \mathrm{C}$ Dextran. Soil Science Society of America Journal 35:914-917.

Papavizas, G.C., J.A. Lewis, and P.B. Adams. 1968. Survival of rootinfecting fungi in soil. II. Influence of amendment and soil carbonto-nitrogen balance on Fusarium root rot of beans. Phytopathology 58:365-372.

Pascual, J.A., C. Garcia, and T. Hernandez. 1999. Lasting microbiological and biochemical effects of the addition of municipal solid waste to an arid soil. Biology and Fertility of Soils 30:1-6.

Pascual, J.A., C. Garcia, T. Hernandez, and M. Ayuso. 1997. Changes in the microbial activity of an arid soil amended with urban organic wastes. Biology and Fertility of Soils 24:429-434.

Percival, G.C., and G.A. Fraser. 2005. Use of sugars to improve root growth and increase transplant success of birch (Betula pendula Roth). Journal of Arboriculture 31(2):66-77.

Percival, G.C., G.A. Fraser, and S. Barnes. 2004. Soil injections of carbohydrates improve fine root growth of established urban trees. Arboriculture Journal 28:1/2:95-101.

Ros, M., M.T. Hernandez, and C. Garcia. 2003. Soil microbial activity after restoration of a semiarid soil by organic amendments. Soil Biology \& Biochemistry 35:463-469.

Sanginga, N., K. Mulongoy, and M.J. Swift. 1992. Contribution of soil organisms to the sustainability and productivity cropping systems in the tropics. Agriculture, Ecosystems \& Environment 41:135-152.

Schmidt, I.K., A. Michelsen, and S. Jonasson. 1997a. Effects on plant production after addition of labile carbon to arctic/alpine soils. Oecologia 112:305-313.

Schmidt, I.K., A. Michelsen, and S. Jonasson. 1997b. Effects of labile soil carbon on nutrient partitioning between an arctic graminoid and microbes. Oecologia 112:557-565.

Schmidt, I.K., L. Ruess, E. Bååth, A. Michelsen, F. Ekelund, and S. Jonasson. 2000. Long-term manipulation of the microbes and microfauna of two subarctic heaths by addition of fungicide, bactericide, carbon and fertilizer. Soil Biology \& Biochemistry 32:707-720.

Smith, J.L., and E.A. Paul. 1990. The significance of soil microbial biomass estimations. In: Bollag, J.M. and G. Sotosky (Eds). Soil Biochemistry, vol. 6, p. 357-396. Marcel Dekker, New York.

Soil Survey Staff. 2004. Official soil series descriptions. Natural Resources Conservation Service U.S. Department of Agriculture. <http:// soils.usda.gov/technical/classification/osd/index.html> 5 May 2008.
Tate, R.L. 2000. Soil microbiology. 2nd Edition. John Wiley \& Sons. Inc., New York.

Tramier, R., and C. Antonini. 1977. Effect of soil amendment with chitin and starch against Fusarium oxysporum f. sp. Dianthi. Acta Horticulturae 71:127-129.

Wagner, G.H., and D.C. Wolf. 2005. Carbon transformation and soil organic matter formation. In: D.M. Sylvia, J.J. Fuhrmann, P.G. Hartel, and D.A. Zuberer (Eds). Principles and applications of soil microbiology, p. 219-258. Pearson Prentice Hall, Englewood Cliffs, NJ.

Wardle, D.A., and D. Parkinson. 1990. Response of the soil microbial biomass to glucose, and selective inhibitors, across a soil moisture gradient. Soil Biology \& Biochemistry 22:825-834.

Wu, J., P.C. Brookes, and D.S. Jenkinson. 1993. Formation and destruction of microbial biomass during the decomposition of glucose and ryegrass in soil. Soil Biology \& Biochemistry 25:1435-1993.

Zuberer, D.A. 1994. Recovery and enumeration of viable bacteria. In: S.H. Mickelson and J.M. Bigham (Eds.). Methods of soil analysis, part 2, Microbiological and biochemical properties. SSSA Book no. 5, p. 119-144. Madison, WI.

Tomás Martínez-Trinidad (corresponding author)

Colegio de Postgraduados-Programa Forestal

Km. 36.5 Carr. Mex-Tex. Montecillo

Texcoco, Edo. de Mexico 56230, Mexico

tomtz@colpos.mx

\section{W. Todd Watson}

Department of Ecosystem Science \& Management

Texas A\&M University

College Station, TX 77843-2138, U.S.

t-watson@tamu.edu

Michael A. Arnold

Department of Horticultural Sciences

Texas A\&M University

College Station, TX 77843-2133, U.S.

ma-arnold@tamu.edu

Leonardo Lombardini

Department of Horticultural Sciences

Texas A\&M University

College Station, TX 77843-2133, U.S.

l-lombardini@tamu.edu 
Résumé. Une recherche a été menée pour analyser l'effet du glucose et de l'amidon par rapport à la respiration dans le sol chez les chênes verts. Le sol dans un champ de production en pépinière a été amendé avec du glucose $\left(\mathrm{C}_{6} \mathrm{H}_{12} \mathrm{O}_{6}\right)$, de l'amidon $\left(\mathrm{C}_{6} \mathrm{H}_{12} \mathrm{O}_{6}\right)$ n, ou un mélange 50:50 de ces deux hydrates de carbone à des concentrations variables $(0$, 40,80 et $120 \mathrm{~g} / \mathrm{L}$ ). Les solutions ont été appliquées une fois par trempage en quantité de $10 \mathrm{~L}$ à $0,5 \mathrm{~m}$ du tronc des chênes verts (Quercus virginiana P. Miller). Dans une étude compagne, des échantillons de sol traités avec les mêmes hydrates de carbone aux mêmes concentrations ont été étudiés sous des conditions de laboratoire. L'évolution du gaz carbonique a été significativement affectée par les applications de glucose et d'amidon. Les applications de glucose ont causé un accroissement significatif de la respiration du sol comparativement aux témoins dans la semaine suivant l'application et cela a duré durant deux à trois semaines. L'augmentation de la respiration du sol n'a pas été notable dans le cadre de l'expérience en champ avec les traitements au moyen de l'amidon; cependant, l'accroissement de la respiration du sol à la concentration la plus élevée $(120 \mathrm{~g} / \mathrm{L})$ n'est pas devenue apparente avant la quatrième semaine après l'application et elle a duré de huit à neuf semaines. Ces connaissances à propos de la durée variable et de la magnitude de l'effet du glucose et de l'amidon sur la respiration du sol pourraient être utiles dans le développement de régimes d'application d'hydrates de carbone pour les sols où l'augmentation de la respiration est désirable dans le cadre de la gestion des arbres urbains.

Zusammenfassung. Hier wurde eine Studie geleitet, um die Auswirkungen von Glukose und Stärke auf die Bodenatmung von Eichen (Quercus virginiana P. Miller) zu untersuchen.Der Boden einer feldgewachsenen Baumschule wurde mit Glukose $\left(\mathrm{C}_{6} \mathrm{H}_{12} \mathrm{O}_{6}\right)$, Stärke $\left(\mathrm{C}_{6} \mathrm{H}_{12} \mathrm{O}_{6}\right)$, oder einer 50:50-Mischung aus beiden Kohlehydraten mit wachsenden Konzentrationen [0, 40, 80 and $120 \mathrm{~g} / \mathrm{L}$ (0, 5.3, 10.6, 16 oz/gal) angereichert. Die Lösungen wurden einmal als 101 Gabe in 0,5 m Abstand vom Stammfuß der Lebenseichen eingebracht. In einer Vergleichsstudie wurden Bodenproben, die mit den gleichen Kohlehydraten zu gleicher Konzentration behandelt wurden, unter Laborbedingungen untersucht. Die Kohlendioxidentwicklung wurde stark durch die
Glukose- und Stärkegaben beeinflusst. Verglichen mit der Kontrolle verursachten die Glukoseapplikationen nach ca. einer Woche einen signifikanten Anstieg der Bodenatmung, welcher zwei bis drei Wochen anhielt. Die erhöhte Bodenatmung war besonders zu beobachten bei dem Feldexperiment mit Stärkebehandlungen. Dennoch konnte ein Anstieg der Bodenatmung bei höheren Konzentrationen [120 g/L (16 oz/gal)] erst in der vierten Woche nach der Applikation verzeichnet werden und hielt für acht bis neun Wochen an. Dieses Wissen über verschiedene Vorhaltezeiträume und Magnituden von Glukose und Stärke bei der Bodenatmung kann nützlich sein bei der Entwicklung von Kohlenhydratapplikationen für Böden, wo eine erhöhte Bodenatmung für die Entwicklung der Bäume erwünscht ist.

Resumen. Se condujo una investigación con el fin de conocer el efecto de la glucosa y almidón en la respiración en el suelo de encinos siempreverdes. El suelo de un vivero de producción de árboles fue mejorado con glucosa $\left(\mathrm{C}_{6} \mathrm{H}_{12} \mathrm{O}_{6}\right)$, almidón $\left(\mathrm{C}_{6} \mathrm{H}_{12} \mathrm{O}_{6}\right)$, o una mezcla 50:50 de ambos carbohidratos con incrementos de concentraciones $[0,40,80 \mathrm{y}$ $120 \mathrm{~g} / \mathrm{L}(0,5.3,10.6,16 \mathrm{oz} / \mathrm{gal})]$. Las soluciones a 10-L (2.6-gal) fueron aplicadas en zanjas a $0.5 \mathrm{~m}$ (1.64 pies) de los troncos de los encinos (Quercus virginiana P. Miller). En un estudio paralelo, muestras de suelo tratadas con los mismos carbohidratos y concentraciones fueron estudiadas bajo condiciones de laboratorio. La evolución del dióxido de carbono fue impactada significativamente por las aplicaciones de glucosas y almidón. Las aplicaciones de glucosa causaron un incremento significativo en la respiración del suelo, comparado con el control dentro de la primera semana después de la aplicación, y las últimas dos o tres semanas. La elevada respiración del suelo fue más notoria en el experimento de campo para los tratamientos con almidón; sin embargo, el incremento en la respiración del suelo para concentraciones más altas [120 g/L (16 oz/ gal)] no fue aparente hasta la cuarta semana después de la aplicación y las últimas ocho o nueve semanas. Este conocimiento acerca de las diferentes duraciones y magnitud de la glucosa y almidón en la respiración del suelo puede ser útil para el desarrollo de regímenes de aplicación de carbohidratos para suelos donde el incremento de la respiración es deseable para el manejo de suelos urbanos. 